\title{
New Dates and Carbon Isotope Assays of Purported Middle Woodland Maize from the Icehouse Bottom and Edwin Harness Sites
}

\author{
Mary L. Simon (D, Kandace D. Hollenbach, and Brian G. Redmond
}

Accelerated mass spectrometry (AMS) and carbon isotope analyses provide strong tandem methodologies used by archaeologists to evaluate and reevaluate the histories of maize use in the Midwest. In this article, we present newly obtained AMS dates and carbon isotope assays of alleged maize samples from the Icehouse Bottom (40MR23) and Edwin Harness sites (22RO33). Based on original studies, samples were thought to date to the Middle Woodland period (ca. 300 BC-AD 400). The results show that samples either were not maize or date to post-AD 900. As of this finding, there are no longer any securely dated Middle Woodland macrobotanical remains of maize from the Eastern Woodlands of North America.

Keywords: maize, Middle Woodland, AMS, carbon isotope, Midwestern United States

La espectrometría de masas acelerada y los análisis de isótopos de carbono proporcionan fuertes metodologías en tándem utilizadas por los arqueólogos para evaluar y reevaluar las historias de uso de maíz en el Medio Oeste. En este artículo presentamos fechas de AMS recién obtenidas y ensayos de isótopos de carbono obtenidos en muestras de maíz de los sitios de Icehouse Bottom (40MR23) y Edwin Harness (22RO33). Según estudios originales, se creía que el maíz de ambos sitios databa del período Middle Woodland (ca. 300 aC a 400 dC). Los resultados de nuevos ensayos muestran que las muestras no eran de maíz o databan mucho más tarde, después de 900 dC. A partir de este hallazgo, ya no hay restos macrobotánicos de Middle Woodland de los bosques orientales de América del Norte.

Palabras clave: maíz, Middle Woodland, AMS, isótopos de carbono, Medio Oeste de los Estados Unidos

$\mathrm{I}$ is important that archaeologists not only collect new data but also continue to reevaluate existing data critically. This is particularly important as the absolute quantity of archaeological data increases, technologies become more sophisticated, and interdisciplinary studies provide deeper and more nuanced understandings of the archaeological record and the people who created it. The history of the search for Middle Woodland maize in the interior midwestern United States provides an excellent example of this process.

At one time, maize agriculture was thought to have been an important component of Middle Woodland (ca. 300 BC-AD 400) subsistence, particularly for the Ohio Hopewell (Griffin 1960; Prufer 1964). This assumption was based on the cultural complexity evident in the archaeological record-in particular, the intricate earthworks and sophisticated material artifacts

Mary L. Simon (msimon1 @illinois.edu corresponding author) — Illinois State Archaeological Survey, 23 Stadium Drive, University of Illinois, Champaign, IL 60182, USA

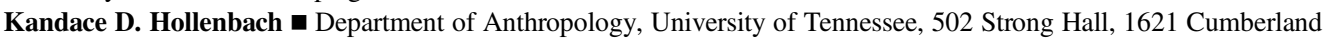
Avenue, Knoxville, TN 37996, USA

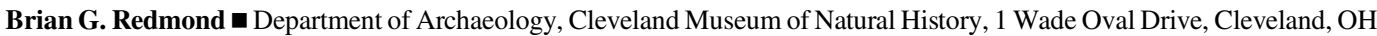
44106-1767, USA

American Antiquity 86(3), 2021, pp. 613-624

Copyright $($ T The Author(s), 2021. Published by Cambridge University Press on behalf of the

Society for American Archaeology. This is an Open Access article, distributed under the terms of the Creative Commons Attribution licence (http://creativecommons.org/licenses/by/4.0/), which permits unrestricted re-use, distribution, and reproduction in any medium, provided the original work is properly cited.

doi:10.1017/aaq.2020.117 


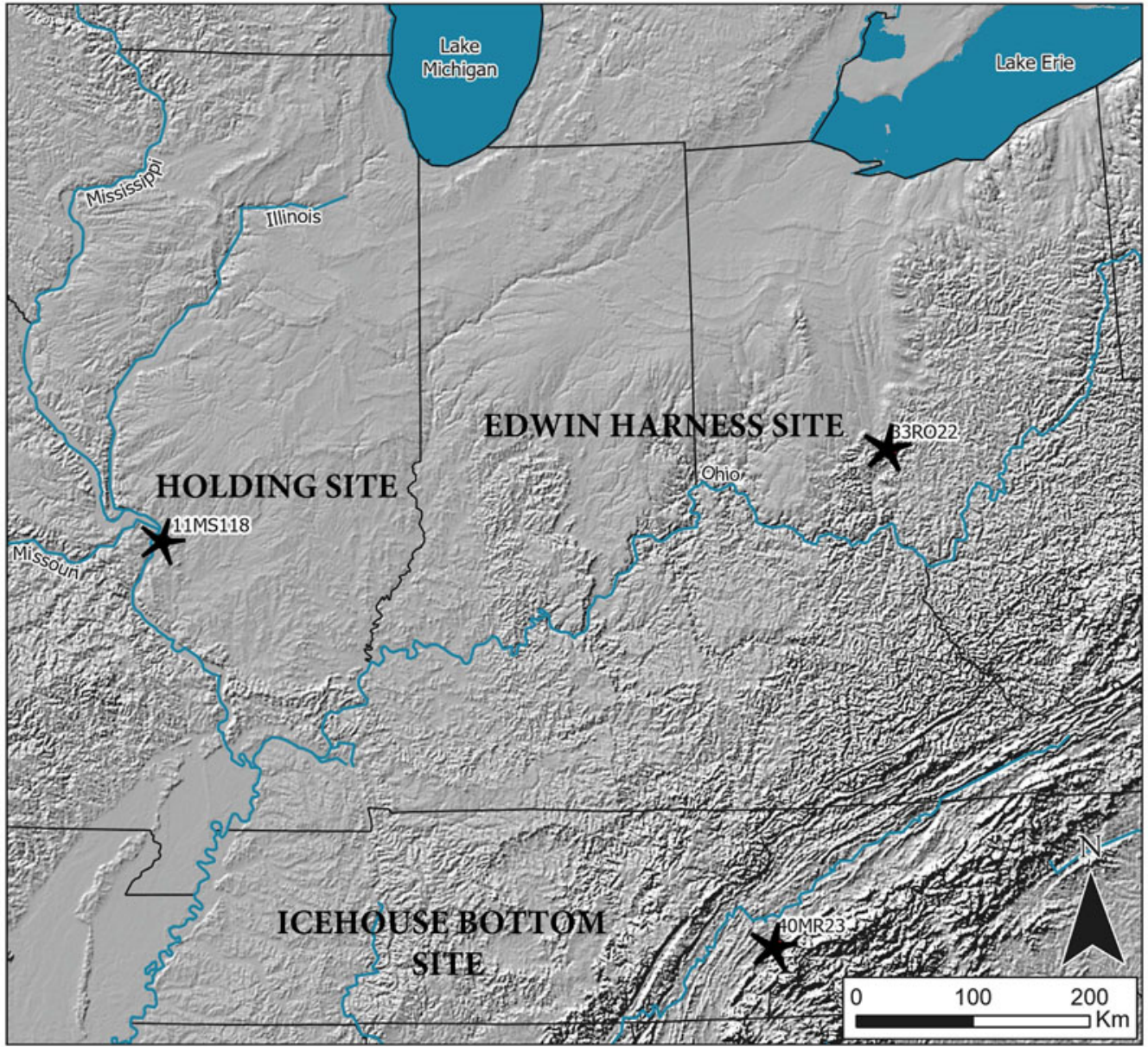

Figure 1. Locations of Edwin Harness (33RO22), Icehouse Bottom (40MR23), and Holding (11MS118) sites. (Figure created by John Lambert, Illinois State Archaeological Survey.)

that signified extensive trade networks, group coordination, and a shared belief system. Clearly, Hopewell society could not have been maintained without an agricultural base, and that base must have been maize. Researchers have since come to realize that maize did not fuel the Hopewell economy while firmly establishing the existence of native crop plants recognized as the "Eastern Agricultural Complex" (Asch and Asch 1985; Fritz 2019:29-43; Mueller 2017; Smith and Cowan 2003; Yarnell 1978), which formed the corpus of native agriculture for centuries before maize. The idea that maize was a significant Hopewellian dietary component was finally put to rest through skeletal isotope studies conducted on Middle Woodland populations, which provided no evidence of ${ }^{13} \mathrm{C}$ enrichment (Bender et al. 1981; van der Merwe and Vogel 1978).

Although they now recognize that maize was not an important component of Middle Woodland diets, researchers are still parsing its earliest history in the interior Midwest. Here, we revisit the topic using a series of new accelerated mass spectrometry (AMS) dates and carbon isotope assays obtained on botanical remains from the Icehouse Bottom (40MR23) and Edwin Harness Mound sites (33RO22; Figure 1). Along with the maize record from the Holding site (11MS118), located in the American Bottom of Illinois, the Icehouse Bottom and Edwin Harness maize records have been frequently cited as evidence for initial (ca. 300 BC-AD 400) maize cultivation in the Eastern Woodlands (Chapman and 
Crites 1987; Riley et al. 1994; Smart and Ford 1983). These records have been supported by the identification of microremains, maize phytoliths, and starch grains, identified in pot residues from northeastern North America and dating to as early as 300 BC (cf. Albert et al. 2018; Boyd et al. 2008; Hart et al. 2007, 2021:Supplemental Table 2; St-Pierre and Thompson 2015).

Recent reevaluation of the alleged maize from the Middle Woodland Holding site has shown that those samples-once thought to be among the oldest in Eastern North America-are either not maize or date to the later, Mississippian component at the site (Simon 2017). Newly obtained AMS and carbon isotope assays on four samples from the Icehouse Bottom site located in Eastern Tennessee and two from the Edwin Harness site in south-central Ohio provide similar results: samples were either not maize or they dated to the late prehistoric (post-cal AD 1000). These new dates eliminate the Icehouse Bottom and Edwin Harness site specimens as the oldest maize macroremains identified in the Eastern Woodlands to date.

\section{Reassessing Maize Records from the Icehouse Bottom and Edwin Harness Sites}

The Edwin Harness mound site is located in Ross County, Ohio. It is part of the Ohio Hopewell Liberty earthworks, and it has been dated to between about cal AD 300 and cal AD 450 (Greber 1983:89). The mound has been the subject of archaeological interest for well over a century, beginning with the work of Squier and Davis (1998 [1848]). Their limited excavations were followed by those of Frederick W. Putnam (1885), Warren K. Moorehead (1897), and William C. Mills (1907). Mills conducted the most extensive excavations, leaving only the lower levels of the mound intact at a height of about $1.5 \mathrm{~m}$.

In 1976, N'omi Greber initiated salvage excavations of the remnant mound. The most noteworthy discovery was a large, multiroom post structure-or "Big House." Beneath this was an extensive clay floor that had numerous deposits of burned material and artifacts, and into which many pits and burials intruded. What appeared to be carbonized maize kernels were found in flotation samples recovered from one burned deposit (Feature 45) and one pit (Features 55/60;
Greber 1983:Table 5.3). Feature 45 consisted of a thin layer of charred and uncharred animal bones and associated artifacts (Greber 1983:33). Feature 60 was a bundle burial found at the bottom of Feature 55, a substantial pit with dimensions of $3.0 \times 2.6 \mathrm{~m}$ and a depth of $55 \mathrm{~cm}$ (Greber 1983:25). The human remains were those of a female estimated to have been between 19 and 22 years at death (Greber 1983:62). The flotation sample containing the fragments identified as maize were taken from the matrix surrounding the bundle burial (Greber 1983:36).

The purported maize kernel fragments from Features 45 and 60 were submitted to Beta Analytic Inc. for AMS radiocarbon dating by Richard I. Ford (1987; Table 1). Based on these results, Ford (1987:10) concluded, "These dates affirm maize from a Hopewell site in Ohio."

The Icehouse Bottom site was located on the first terrace of the Little Tennessee River in Monroe County, Tennessee (Figure 1). Salvage excavations were undertaken prior to the construction of Tellico Dam and inundation of the site. These efforts yielded cultural materials reflecting occupations during the Late Archaic, Middle Woodland, and Mississippian periods (Cridlebaugh 1981). The Middle Woodland component was readily distinguishable from the overlying plow zone at depths ranging from $6.1 \mathrm{~cm}$ to $36.3 \mathrm{~cm}$ below surface. Flotation samples from that context were analyzed by Andrea Brewer Shea, who identified 107 specimens of Zea mays, including 81 kernel fragments, 3 whole and 21 fragmented cupules, and 2 whole glumes distributed among 5 features and 37 midden contexts (Chapman and Crites 1987; Cridlebaugh 1981:174). Chapman and Crites (1987:353) submitted one kernel fragment from Feature 609, a small pit located near the base of Stratum II (72 cm below surface), to Beta Analytic for an AMS date (Table 1). At the time, these finds were recognized as comprising "the most convincing early date for maize in the east" (Chapman and Crites 1987:353).

\section{Methods of Analysis}

Reevaluation of the Middle Woodland maize from both Icehouse Bottom and Edwin Harness was initiated in the spring of 2019. Samples from the Icehouse Bottom site, curated at the 


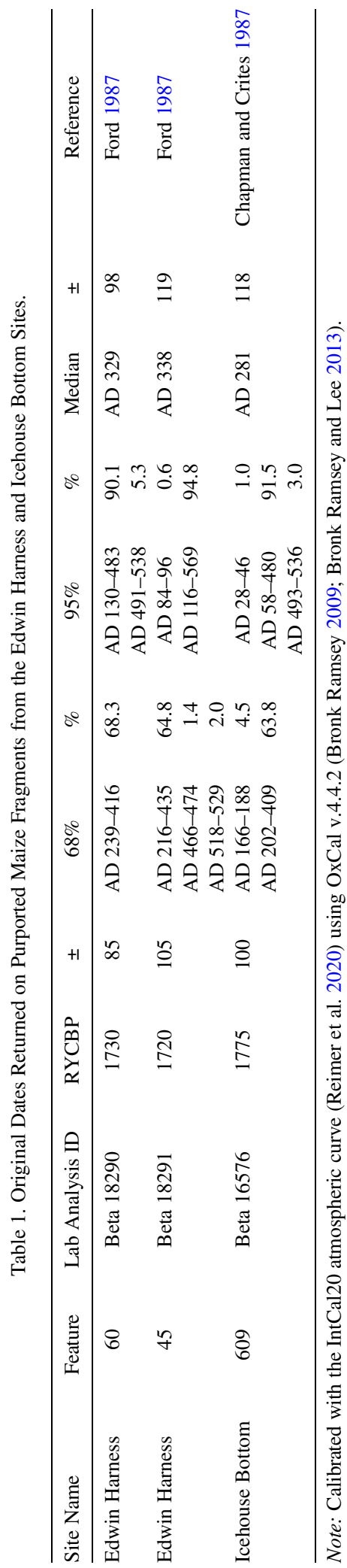

McClung Museum of Natural History and Culture in Knoxville, Tennessee, and from the Edwin Harness Mound site, curated at the Cleveland Museum of Natural History, were supplied to the lead author. Although samples from each site had been previously dated using AMS technology, obtaining direct carbon isotope ratios on the samples themselves was not standard protocol at that time. Adjustments for enrichment were made using the identification supplied by the institution requesting that date. Consequently, although the dates were sound, secure identifications as maize based on $\delta^{13} \mathrm{C}$ values were not available.

Eight specimens from the Icehouse Bottom, two each from four different contexts, were selected and sent to the Illinois State Archaeological Survey (ISAS) by Kandace Hollenbach. Only specimens recovered below Level 2 of the Middle Woodland midden (Stratum II) were considered, given that Cridlebaugh (1981:174) noted the possibility of inclusion of plow zone materials in Level 2. Two cupules (PB74) and one kernel fragment and cupule (PB12) were selected based on their clearly identifiable form and texture. Specimen PB74 derived from Level 3 of Unit 115R115, and PB12 from Level 3 of Unit 110R125. An additional two cupules (PB93) and two kernel fragments (PB52) were selected from two sealed feature contexts. Specimen PB93 derives from Feature 610, a small globular pit with fire-reddened edges originating in Level 7 of Unit 115R120. Specimen PB52 derives from Feature 597, a pit with limestone-tempered pottery first recognized in Level 8 of Unit 110R120/125 (Chapman 1977; Cridlebaugh 1981; Denny 1977). Four of the eight samplesone from each specific context-were submitted for dating.

Bulk flotation samples from the Edwin Harness site curated at the Cleveland Museum of Natural History were sent to ISAS for assessment. All samples were scanned by ISAS lab personnel for the presence of maize. The only potential maize identified was from float 71A, taken from Feature 60-the burial that had yielded one of the original dated samples. Two fragments of possible maize kernels were removed from the flotation sample for dating purposes.

All items slated for AMS dating and carbon isotope assays were photographed under 
magnifications ranging from $6 \times$ to $32 \times$. Samples were then submitted to the Isotope Dating Laboratory of the Illinois State Geological Survey (ISGS) at the University of Illinois for processing. Samples were converted to pure carbon, and $\delta^{13} \mathrm{C}$ ratios were obtained using a Carlo-Erba Elemental Analyzer attached to a Thermo Fisher Scientific Delta V Isotope Ratio Mass Spectrometer. Sealed samples were sent to the Accelerated Mass Spectrometer Laboratory at the University of California Irvine for counting. The results of these analyses were submitted to ISAS in July and December, 2019. All dates were calibrated to calendric age using OxCal v.4.4.2 (Bronk Ramsey 2009; Bronk Ramsey and Lee 2013; IntCal20 atmospheric curve [Reimer et al. 2020]).

\section{Results}

The results of these analyses are presented in Table 2 and Figure 2. Despite yielding good Middle Woodland dates, four of the samplestwo from Icehouse Bottom and the two from Edwin Harness-produced $\delta^{13} \mathrm{C}$ ratios that fall within the range for $\mathrm{C}_{3}$ plants, nullifying their original identifications as maize. The Edwin Harness samples are curved and resemble kernels in texture, but they are quite small (Figures $3 \mathrm{a}$ and $3 \mathrm{~b}$ ). The Icehouse Bottom samples were maize-like in texture and form (Figure 4a alleged kernel, and Figure 4b alleged cupule), but in neither case were morphological indicators strong.

In contrast, the two additional samples from Icehouse Bottom provided $\delta^{13} \mathrm{C}$ assays that verified their identification as maize. These samples were larger than the other four, and even before assayed, they were identifiable as a probable cupule and kernel fragment (Figures 5a and $5 b)$. In both cases, the dates returned indicated that each was associated with the Mississippian occupation at this site.

\section{The Importance of Isotopic Confirmation for Maize Identification}

In this study, small fragments originally identified as maize from the Icehouse Bottom and Edwin Harness sites were shown to be derived from $\mathrm{C}_{3}$ plants. Possibly, they are tuber fragments, although this cannot be confirmed at this time. Those fragments correctly identified as maize were shown to postdate AD 1000, and they are not Middle Woodland in age.

The non-maize materials from the Icehouse Bottom and Edwin Harness sites were morphologically similar to those reported from the Middle Woodland Holding site (Simon 2017). The latter samples include small, shiny fragments thought to be kernels and porous-textured fragments that approximate cupule base bits. The results of these recent studies demonstrate that visual identification based on texture alone is insufficient for identifying small botanical fragments as maize.

Larger fragments retaining distinct morphological characteristics are less problematic, as demonstrated by reassessment of maize from western Illinois (Simon 2014). However, in almost all our evaluations of Middle and early Late Woodland maize remains where identifications were confirmed, the samples returned dates much younger than suggested by context (Simon 2014, 2017). Clearly, for open-air sites in the eastern United States, context alone can be an inadequate measure of antiquity, particularly for sites with multiple components. Obviously, not every maize fragment recovered from the archaeobotanical record can be AMS dated. Maize recovered in association with Middle and even early Late Woodland contexts in the interior Midwest, however, should be considered suspect and, if possible, both dated and verified through isotopic analysis.

Recent studies have highlighted the fact that there are some terrestrial $\mathrm{C}_{4}$ plants native to the study area. These include Portulaca oleracea, a few forbs in the Amaranthaceae family (Amaranthus spp., Chenopodium spp., but not Chenopodium berlandieri), and some of the more common native prairie grasses. Portulaca in particular has been cited as a potential component of the diet for people living in temperate regions, possibly impacting carbon isotope values obtained from skeletal remains and in vessel residues (Reber et al. 2020; Tankersley et al. 2016). Although a consideration for isotope studies, it is unlikely that the small seeds of these taxa would be mistaken for maize or identified as such in the archaeological record. In fact, as illustrated here and in earlier studies, morphologically 
Table 2. Calibrated Accelerated Mass Spectrometry Dates on Samples from the Icehouse Bottom and Edwin Harness Sites.

\begin{tabular}{|c|c|c|c|c|c|c|c|c|c|c|c|c|c|c|c|}
\hline Feature Type & Material & $\begin{array}{c}\text { Site } \\
\text { Number }\end{array}$ & Site Name & $\begin{array}{c}\text { ISGS } \\
\text { Identifier }\end{array}$ & $\begin{array}{c}\text { ISAS } \\
\text { Identifier }\end{array}$ & ${ }^{13} \mathrm{C}$ Ratio & RCYBP & $\begin{array}{l}\text { Standard } \\
\text { Deviation }\end{array}$ & $68.2 \%$ & $\%$ & $95.4 \%$ & $\%$ & Median & \pm & $\begin{array}{c}\text { McClung } \\
\text { Museum } \\
\text { Sample } \\
\text { Numbers }\end{array}$ \\
\hline $\begin{array}{c}\text { Level } 3 \text { Unit } \\
\text { 115R115 }\end{array}$ & $\begin{array}{l}\text { maize: cupule } \\
\text { fragment }\end{array}$ & 40MR23 & $\begin{array}{l}\text { Icehouse } \\
\text { Bottom }\end{array}$ & A4765 & CI-984 & -10.0 & 710 & 20 & AD $1277-1292$ & 68.3 & AD 1271-1302 & 91.7 & $\mathrm{AD} 1285$ & 22 & PB74 \\
\hline \multirow[t]{2}{*}{$\begin{array}{l}\text { Level } 3 \text { Unit } \\
\quad 11119 \mathrm{R} 125\end{array}$} & $\begin{array}{l}\text { maize: kernel } \\
\text { fragment }\end{array}$ & 40MR23 & $\begin{array}{l}\text { Icehouse } \\
\text { Bottom }\end{array}$ & A4766 & CI-985 & -8.7 & 905 & 15 & AD 1052-1079 & 39.2 & $\begin{array}{l}\text { AD 1371-1378 } \\
\text { AD 1046-1085 }\end{array}$ & $\begin{array}{r}3.7 \\
42.6\end{array}$ & AD 1140 & 54 & PB12 \\
\hline & & & & & & & & & AD 1155-1176 & 29.1 & $\begin{array}{l}\text { AD 1098-1102 } \\
\text { AD 1126-1214 }\end{array}$ & $\begin{array}{r}0.6 \\
52.2\end{array}$ & & & \\
\hline \multirow[t]{2}{*}{ Pit Feature 597} & $\begin{array}{c}\text { charcoal (NOT } \\
\text { MAIZE) }\end{array}$ & 40MR23 & $\begin{array}{l}\text { Icehouse } \\
\text { Bottom }\end{array}$ & A4836 & CI-991 & -27.5 & 1415 & 25 & AD 606-626 & 33.8 & AD 600-660 & 95.4 & AD 630 & 17 & PB52 \\
\hline & & & & & & & & & AD $636-654$ & 34.5 & & & & & \\
\hline \multirow[t]{4}{*}{ Pit Feature 610} & $\begin{array}{c}\text { charcoal (NOT } \\
\text { MAIZE) }\end{array}$ & 40MR23 & $\begin{array}{l}\text { Icehouse } \\
\text { Bottom }\end{array}$ & A4837 & CI-992 & -28.1 & 1575 & 25 & AD 435-466 & 26.0 & AD 425-556 & 95.4 & AD 488 & 38 & PB93 \\
\hline & & & & & & & & & AD 474-503 & 24.2 & & & & & \\
\hline & & & & & & & & & AD 507-517 & 6.6 & & & & & \\
\hline & & & & & & & & & AD 530-544 & 11.5 & & & & & \\
\hline \multirow[t]{2}{*}{$\begin{array}{l}\text { Burial Feature } \\
\text { F60 Float } \\
71 \mathrm{~A}\end{array}$} & $\begin{array}{c}\text { charcoal (NOT } \\
\text { MAIZE) }\end{array}$ & 33RO22 & $\begin{array}{l}\text { Edwin } \\
\text { Harness }\end{array}$ & A4767 & CI-986 & -21.0 & 1810 & 20 & AD 236-252 & 30.5 & AD 226-257 & 41.2 & AD 291 & 33 & N/A \\
\hline & & & & & & & & & AD $293-316$ & 37.7 & AD 284-327 & 54.2 & & & \\
\hline \multirow[t]{2}{*}{$\begin{array}{l}\text { Burial F60 Float } \\
\quad 71 \mathrm{~A}\end{array}$} & $\begin{array}{c}\text { charcoal (NOT } \\
\text { MAIZE) }\end{array}$ & $33 \mathrm{RO} 22$ & $\begin{array}{l}\text { Edwin } \\
\text { Harness }\end{array}$ & A4768 & CI-987 & -21.4 & 1795 & 15 & AD 215-250 & 53.4 & AD 207-257 & 64.9 & AD 241 & 38 & N/A \\
\hline & & & & & & & & & AD 296-310 & 14.9 & $\mathrm{AD} 284-327$ & 30.5 & & & \\
\hline
\end{tabular}

Note: Calibrated with the IntCal20 atmospheric curve (Reimer et al. 2020) using OxCal v.4.4.2 (Bronk Ramsey 2009; Bronk Ramsey and Lee 2013). 


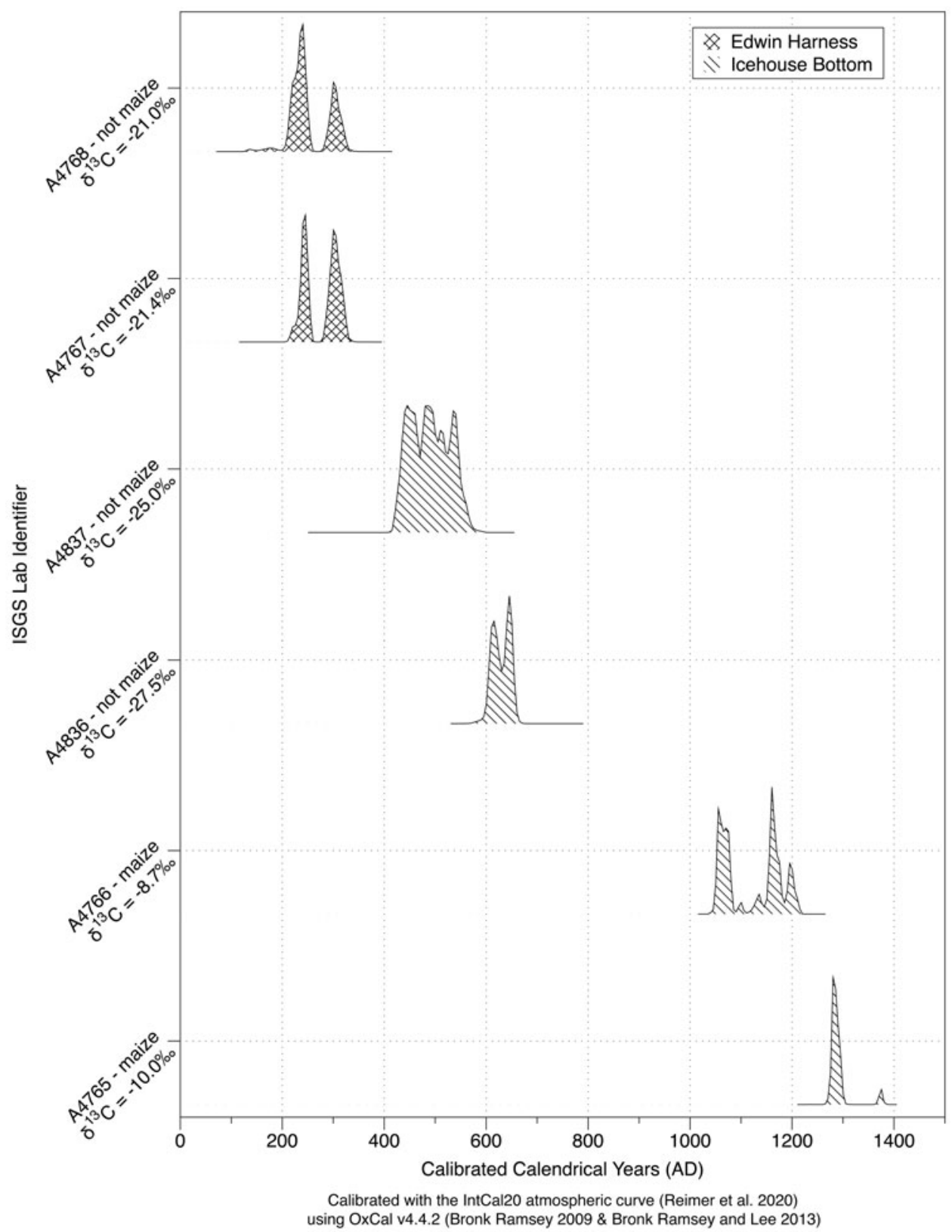

Figure 2. Calibrated accelerated mass spectrometry dates from Icehouse Bottom and Edwin Harness samples. (Figure created by Mathew Fort, Illinois State Archaeological Survey.)

ambiguous remains tend to produce $\delta^{13} \mathrm{C}$ ratios characteristic of $\mathrm{C}_{3}$ plants (Simon 2017).

\section{The Case for Middle Woodland Maize}

Along with revised records for macroremains at the Holding site in Illinois (Simon 2017), the
Icehouse Bottom and Edwin Harness dates reported here cast further doubt on the model for gradually increasing maize use beginning in the Middle Woodland in the interior Midwest. Importantly, these records do not deny the occasional presence of maize at an early date; it is possible that people occasionally obtained 
(a)

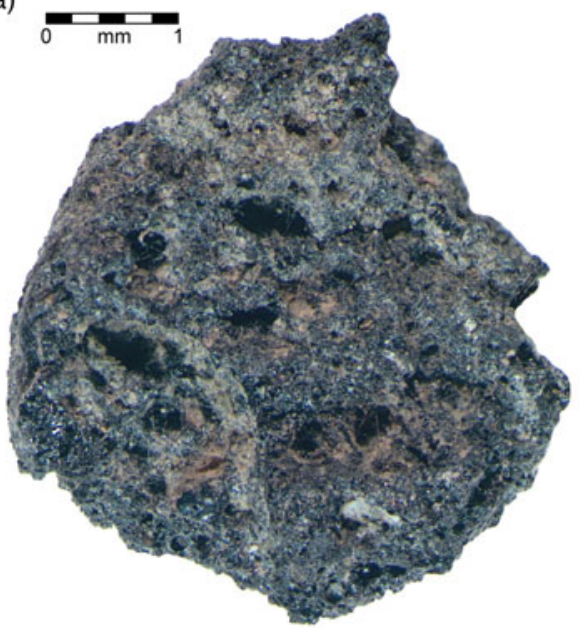

(b)

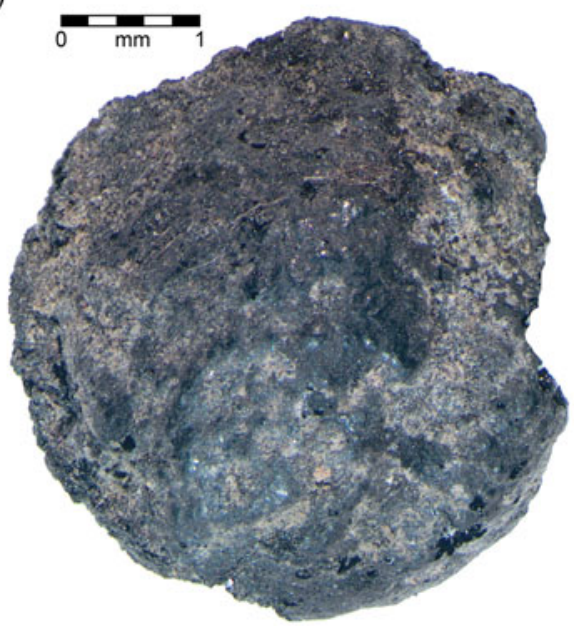

Figure 3. (a) Edwin Harness Site Sample 1, not maize (ISGS A4767; 20x); (b) Edwin Harness Site Sample 2, not maize (ISGS A4768; 20x), illustrating characteristic glossy surface and porous interior. (Photographed by Mary Simon, Illinois State Archaeological Survey.) (Color online)

(a)

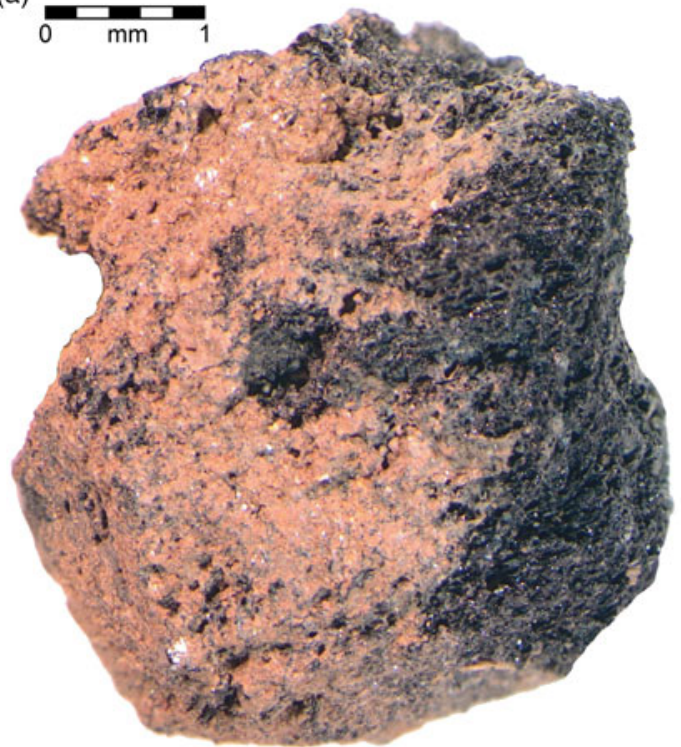

(b)

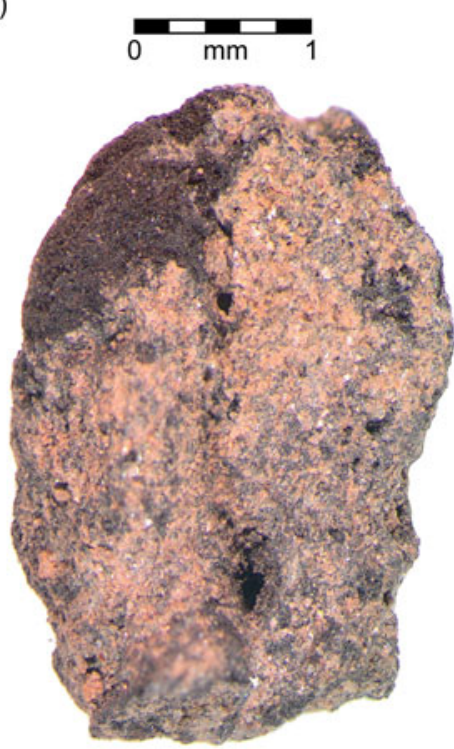

Figure 4. (a) Icehouse Bottom Site Sample 1, kernel-like texture, not maize (ISGS A4836; 20x); (b) Icehouse Bottom Site Sample 2, cupule-like texture, not maize (ISGS A4837; 20x). (Photographed by Mary Simon, Illinois State Archaeological Survey.) (Color online)

seeds and tried to grow them. It does, however, suggest that any early attempts at sustained cultivation in this area were limited or unsuccessful. This is supported by a growing body of directly dated maize and skeletal isotope data from sites in Illinois centering on the American Bottom region (Emerson et al. 2020; Reber 2006; Simon 2014, 2017). Aside from one maize fragment from the Edward Hoener site in western Illinois (cal AD 657-775; Simon 2014), that work has failed to produce any materials with calibrated median ages predating AD 900. 
(a)

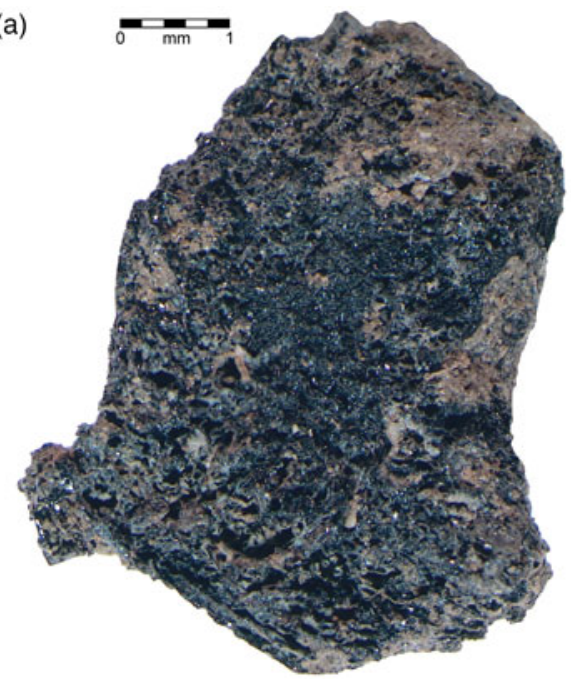

(b)

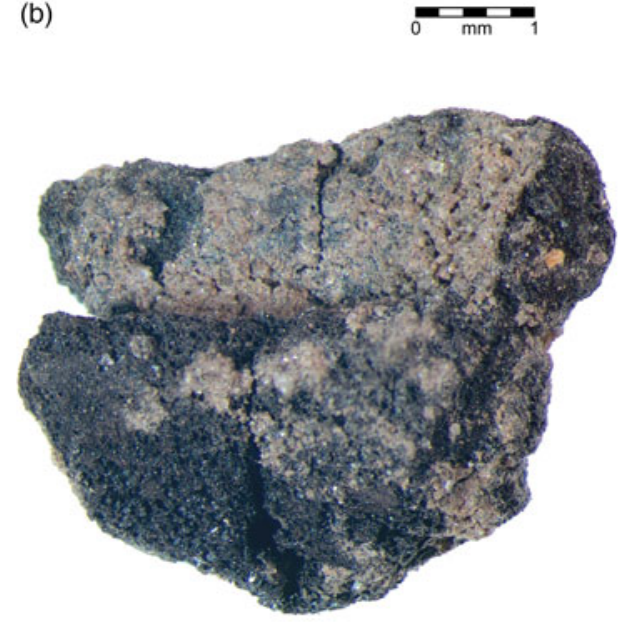

Figure 5. (a) Mississippian kernel fragment from Icehouse Bottom Site (ISGS A4765; 32×); (b) Mississippian cupule from Icehouse Bottom Site (ISGS A4766; 16x). (Photographed by Mary Simon, Illinois State Archaeological Survey.) (Color online)

The idea that maize was introduced at a later date than previously thought is not unprecedented (cf. Fritz 1994). Nor is the dismissal of Hopewellian period maize based on direct AMS dates, as reported for the Jasper Newman site in Illinois (Conard et al. 1984). In fact, there have been several high-profile cases where "the antiquity of a particular crop has been shortened . . . rather than lengthened" (Langlie et al. 2014:1606) through use of direct radiocarbon dating. Although speaking more specifically to locations of plant domestications and the pace of plant domestication processes, this statement may also apply to crop introductions-in this case, maize in the interior Midwest.

\section{Toward Reconciling Conflicting Records}

The earliest evidence for the presence of maize in the Eastern Woodlands comes from maize phytoliths in food residues on ceramic vessels from the Vinnette site in New York State (Hart et al. 2007). Residues dating to between approximately $300 \mathrm{BC}$ and $\mathrm{AD} 600$ containing maize microremains have also been reported from nine additional sites located in New York, Michigan, and Ontario (Hart et al. 2021:Supplemental Table 2). No macroremains of that antiquity from the region have yet been identified, although directly dated samples from four sites are in the AD 700-900 range. Those records cannot be ignored or dismissed out of hand. We note, however, that these botanical samples have not been verified as maize through carbon isotopic analysis. The paucity of macroremains from pre-AD 700 contexts has raised the possibility that maize first entered Eastern North America in the form of ground kernels, traded in to the region on a limited basis (Langlie et al. 2014:1609). This idea has also been presented by others as a means of explaining microremains from pre-AD 700 pot residues from sites in the northern Great Lakes region (Albert et al. 2018; Boyd et al. 2008:2551).

The differences between maize records are clearly geographical, with microbotanical records from the Northeast providing a much older and deeper timeline. The mechanisms for introduction and adaptation in that region have been summarized by Hart and Lovis (2013; see also Hart 1999, 2014). This model highlights the genetic and social complexities involved in the process and relies on a series of founder events coupled with plant adaptations to local environments within the framework of human population management. This resulted in a "gradual dispersal of highly productive landraces of Northern Flint, adapted to local conditions" 
(Hart and Lovis 2013:182). Although this may very well reflect maize histories in the Northeast, it does not apply to the interior Midwest, based on the macrobotanical record.

One of the key components for understanding the variability in maize histories lies in assessing the timing of genetic changes necessary before a tropical plant could flourish in the temperate Eastern Woodlands. Several decades ago, Gayle Fritz (1994) noted that tropical maize adapted to conditions on the Colorado Plateau would likely also survive in latitudes to the east. This adaptation required a suppression of photoperiodism, which controls flowering time in tropical races (Adams 2015:17-18). It was absolutely necessary for plants to survive and produce seeds under conditions of day length and short growing seasons that characterize temperate Eastern North America. Ancient DNA studies on desiccated remains from sites in the Southwest are contributing to our understanding of this transition as well as other important changes, including production of floury kernels with appropriate pasting qualities that permit production of fine flour (da Fonseca et al. 2015). Ancient DNA from maize recovered from the Turkey Pen site in southeast Utah and dated to about 1,900 years ago (mean calibrated dates $1864 \pm 11$ and $1882 \pm 8$ RCYBP [Swarts et al. 2017:513]) suggests that plants were only marginally adapted to this latitude in terms of flowering time by this date (Swarts et al. 2017). If this is broadly applicable to maize in general, it has important implications for understanding maize histories in regions well outside the plant's natural range.

\section{Concluding Remarks}

The results presented here substantiate what has long been recognized. For the interior Midwest, the incorporation of maize agriculture into the subsistence economy postdates approximately AD 900 at the very earliest (Fritz 1994; see Fritz [2019] for summary). Furthermore, we have no evidence for even its presence, much less widespread cultivation, in this region from any earlier than approximately AD 700. We recognize that there is no reason that maize histories across the Eastern Woodlands have to follow the same timetable, but we reiterate that, regardless of its ultimate significance, clearly Native Americans thrived for millennia prior to the introduction of maize.

Acknowledgments. The lead author would like to thank her colleagues, past and present, from the Illinois State Archaeological Survey (ISAS), University of Illinois, for their help and support. In particular, I would like to thank Dr. Thomas Emerson, Director Emeritus, for his unfailing support of my ongoing project investigating the antiquity of maize in the Eastern Woodlands. Mary King, ISAS Research Archaeologist, scanned the Edwin Harness samples for additional maize fragments (none were found). Mathew Fort, ISAS and ISGS, processed the samples and created Table 1 and Figure 2 for publication. Figure 1 was created by John Lambert, ISAS, for my 2019 Plains Conference presentation. Four of the AMS dates reported in this article were funded by ISAS, initiated under the direction of Dr. Emerson and completed under the direction of current director Dr. Timothy Pauketat. Two additional dates were funded by the Department of Anthropology, University of Tennessee. I would also like to thank my coauthors, Dr. Kandace Hollenbach and Dr. Brian Redmond, for agreeing to take on this project and submit old samples for reevaluation. Without their help, this study could not have been conducted. We also thank Dr. Jeff Chapman and Dr. Tim Baumann at the McClung Museum of Natural History and Culture at the University of Tennessee, Knoxville, for their guidance in selecting Icehouse Bottom samples.

Data Availability Statement. Data available upon request from Illinois State Archaeological Survey, 23 Stadium Drive, University of Illinois, Champaign, Illinois 61820.

\section{References Cited}

Adams, Karen R.

2015 The Archaeology and Agronomy of Ancient Maize (Zea mays L.). In Traditional Arid Lands Agriculture, edited by Scott E. Ingram and Robert C. Hunt, pp. 1553. University of Arizona Press, Tucson.

Albert, Rebecca K., Susan M. Kooiman, Caitlin A. Clark, and William A. Lovis

2018 Earliest Microbotanical Evidence for Maize in the Northern Lake Michigan Basin. American Antiquity 83:345-355.

Asch, David L., and Nancy B. Asch

1985 Prehistoric Plant Cultivation in West Central Illinois. In Prehistoric Food Production in North America, edited by Richard I. Ford, pp. 149-203. University of Michigan Anthropological Papers No. 75. Museum of Anthropology, Ann Arbor, Michigan

Bender, Margaret M., David A. Barreis, and Raymond L. Steventon

1981 Further Light on Carbon Isotopes and Hopewell Agriculture. American Antiquity 46:354-361.

Boyd, Mathew, Tamara Varney, Clarence Surette, and Jennifer Surette

2008 Reassessing the Northern Limit of Maize Consumption in North America: Stable Isotope, Plant Microfossil, 
and Trace Element Content of Carbonized Food Residue. Journal of Archaeological Science 35:2545-2556.

Bronk Ramsey, Christopher

2009 Bayesian Analysis of Radiocarbon Dates. Radiocarbon 51:337-360.

Bronk Ramsey, Christopher, and Sharen Lee

2013 Recent and Planned Developments of the Program OxCal. Radiocarbon 55:720-730.

Chapman, Jefferson

1977 Feature 610. 40MR23 field paperwork. Manuscript on file at the McClung Museum of Natural History and Culture, University of Tennessee, Knoxville.

Chapman, Jefferson, and Gary D. Crites

1987 Evidence for Early Maize (Zea mays) from the Icehouse Bottom Site, Tennessee. American Antiquity 52:352-354.

Conard, Nicholas, David L. Asch, Nancy B. Asch, David Elmore, Harry Grove, Meyer Rubin, James A. Brown, Michael D. Wiant, and Thomas G. Cook

1984 Accelerator Radiocarbon Dating of Evidence for Prehistoric Horticulture in Illinois. Nature 308:443-446.

Cridlebaugh, Patricia

1981 The Icehouse Bottom Site: 1977 Excavations. Reports of Investigations No. 35. Department of Anthropology, University of Tennessee, Knoxville.

da Fonseca, Ruta R., Bruce D. Smith, Nathan Wales, Enrico Cappellini, Pontus Skoglund, Matteo Fumagalli, José Alfredo Samaniego, Christian Carøe, María C. Ávila-Arcos, David E. Hufnagel, Thorfinn Sand Korneliussen, Filipe Garrett Vieira, Mattias Jakobsson, Bernardo Arriaza, Eske Willerslev, Rasmus Nielsen, Matthew B. Hufford, Anders Albrechtsen, Jeffrey Ross-Ibarra, and M. Thomas P. Gilbert

2015 The Origin and Evolution of Maize in the Southwestern United States. Nature Plants 1:Article 14003. DOI:10.1038/nplants.2014.3.

Denny, David

1977 Feature 597. 40MR23 field paperwork. Manuscript on file at the McClung Museum of Natural History and Culture, University of Tennessee, Knoxville.

Emerson, Thomas E., Kristin M. Hedman, Mary L. Simon, Mathew A. Fort, and Kelsey E. Witt

2020 Isotopic Confirmation of the Timing and Intensity of Maize Consumption in Greater Cahokia. American Antiquity 85:241-262

Ford, Richard I.

1987 Dating Early Maize in the Eastern United States. Paper presented at the 153rd American Association for the Advancement of Science Annual Meeting, Chicago, Illinois.

Fritz, Gayle J.

1994 Are the First American Farmers Getting Younger? Current Anthropology 35:305-309.

2019 Feeding Cahokia: Early Agriculture in the North American Heartland. University of Alabama Press, Tuscaloosa.

Greber, N'omi (editor)

1983 Recent Excavations at the Edwin Harness Mound, Liberty Works, Ross County Ohio. Midcontinental Journal of Archaeology Special Paper No 5. Kent State University Press, Kent, Ohio.

Griffin, James B.

1960 Climate Change: A Contributory Cause of the Growth and Decline of Northern Hopewell Culture. Wis consin Archeologist 41(3):21-33.
Hart, John P

1999 Maize Agriculture Evolution in the Eastern Woodlands of North America: A Darwinian Perspective. Journal of Archaeological Method and Theory $6: 137-180$

2014 A Critical Assessment of Current Approaches to Investigations of the Timing, Rate, and Adoption Trajectories of Domesticates in the Midwest and Great Lakes. In Reassessing the Timing, Rate, and Adoption Trajectories of Domesticate Use in the Midwest and Great Lakes, edited by Maria E. Raviele and William A. Lovis, pp. 161-174. Occasional Papers No. 1. Midwest Archaeological Conference, Champaign, Illinois.

Hart, John P., Hetty Jo Brumbach, and Robert Lusteck

2007 Extending the Phytolith Evidence for Early Maize (Zea mays ssp. mays) and Squash (Cucurbita sp.) in Central New York. American Antiquity 72:563-583.

Hart, John P., and William A. Lovis

2013 Reevaluating What We Know about the Histories of Maize in Northeastern North America: A Review of Current Evidence. Journal of Archaeological Research 21:175-216.

Hart, John P., William A. Lovis, and Anne M. Katzenberg

2021 Early Maize in Northeastern North America: A Comment on Emerson and Colleagues. American Antiquity, in press.

Langlie, BrieAnna S., Natalie G. Mueller, Robert N. Spengler, and Gayle J. Fritz

2014 Agricultural Origins from the Ground Up: Archaeological Approaches to Plant Domestication. American Journal of Botany 101:1601-1617.

Mills, William C.

1907 Explorations of the Edwin Harness Mound. Ohio Archaeological and Historical Quarterly 16:113-193.

Moorehead, Warren K.

1897 Report of Field Work Carried Out in the Muskingum, Scioto, and Ohio Valley during the Season of 1866. Ohio Archaeological and Historical Quarterly $5: 165-274$

Mueller, Natalie

2017 An Extinct Domesticated Subspecies of Erect Knotweed in Eastern North America: Polygonum erectum subsp. watsoniae (Polygonaceae). Novon 25:166-179.

Prufer, Olaf $\mathrm{H}$.

1964 The Hopewell Cult. Scientific American 211(6):90105.

Putnam, Frederick W.

1885 Explorations of the Harness Mounds in the Scioto Valley Ohio. Peabody Museum Reports 3(5-6):449466.

Reber, Eleanora A.

2006 A Hard Row to Hoe: Changing Maize Use in the American Bottom and Surrounding Areas. In Histories of Maize: Multidisciplinary Approaches to the Prehistory, Linguistics, Biogeography, Domestication, and Evolution of Maize, edited by John Staller, Robert Tykot, and Bruce Benz, pp. 235-248. Academic Press, Burlington, Massachusetts.

Reber, Eleanora A., John E. Kelly, Elizabeth Boswell, and Chad S. Lane

2020 Molecular Evidence of Changing Foodways across the Mississippian Transition at the George Reeves Site (11S650). Southeastern Archaeology 39:71-88.

Reimer, Paula J., William E. N. Austin, Edouard Bard, Alex Bayliss, Paul G. Blackwell, Christopher Bronk Ramsey, Martin Butzin, Hai Cheng, R. 
Lawrence Edwards, Michael Friedrich, Pieter M. Grootes, Thomas P. Guilderson, Irka Hajdas, Timothy J. Heaton, Alan G. Hogg, Konrad A. Hughen, Bernd Kromer, Sturt W. Manning, Raimund Muscheler, Jonathan G. Palmer, Charlotte Pearson, Johannes van der Plicht, Ron W. Reimer, David A. Richards, E. Marian Scott, John R. Southon, Christian S. M. Turney, Lukas Wacker, Florian Adolphi, Ulf Büntgen, Manuela Capano, Simon M. Fahrni, Alexandra Fogtmann-Schulz, Ronny Friedrich, Peter Köhler, Sabrina Kudsk, Fusa Miyake, Jesper Olsen, Frederick Reinig, Minoru Sakamoto, Adam Sookdeo, and Sahra Talamo

2020 The IntCal20 Northern Hemisphere Radiocarbon Age Calibration Curve (0-55 cal kBP). Radiocarbon 62:1-33.

Riley, Thomas J., Gregory R. Walz, Charles J. Bareis, Andrew C. Fortier, and Kathryn E. Parker

1994 Accelerator Mass Spectrometry (AMS) Dates Confirm Early Zea Mays in the Mississippi River Valley. American Antiquity 59:490-498.

Simon, Mary L.

2014 Reevaluating the Introduction of Maize into the American Bottom and Western Illinois. In Reassessing the Timing, Rate, and Adoption Trajectories of Domesticate Use in the Midwest and Great Lakes, edited by Maria E. Raviele and William A. Lovis, pp. 97-134. Midwest Archaeological Conference, Champaign Illinois.

2017 Reevaluating the Evidence for Middle Woodland Maize from the Holding Site. American Antiquity 82:140-150.

Smart, Tristine Lee, and Richard I. Ford

1983 Plant Remains. In Recent Excavations at the Edwin Harness Mound, Liberty Works, Ross County Ohio, edited by N'omi Greber, pp. 54-58. Kent State University Press, Kent, Ohio.

Smith, Bruce D., and C. Wesley Cowan

2003 Domesticated Crop Plants and the Evolution of Food Producing Economies in Eastern North America. In People and Plants in Ancient Eastern North America, edited by Paul E. Minnis, pp. 105-125. Smithsonian Institution, Washington, DC.

Squier, Ephraim G., and Edwin H. Davis

1998 [1848] Ancient Monuments of the Mississippi Valley. Edited and with an Introduction by David J. Meltzer. Smithsonian Institution, Washington, DC.

St-Pierre, Christian Gates, and Robert G. Thompson

2015 Phytolith Evidence for the Early Presence of Maize in Southern Quebec. American Antiquity 80:408-415.

Swarts, Kelly, Rafal M. Grutaker, Bruce Benz, Michael Blake, Robert Bukowski, James Holland, Melissa Kruse-Peeples, Nicholas Lepak, Lynda Prim, M. Cita Romay, Jeffery Ross-Ibarra, Jose de Jesus Sanchez-Gonzalez, Chris Schmidt, Verena J. Schuenemann, Johannes Krause, R. G. Matson, Detlef Weigel, Edward S. Buckler, and Hernán A. Burbano

2017 Genomic Estimation of Complex Traits Reveals Ancient Maize Adaptation to Temperate North America. Science 357:512-515.

Tankersley, Kenneth Barnett, Dennis G. Conover, and David L. Lentz

2016 Stable Carbon Isotope Values $\delta^{13} \mathrm{C}$ of Purslane (Portulaca oleracea) and Their Archaeological Significance. Journal of Archaeological Science 7:189-194.

van der Merwe, Nikolaas, and J. C. Vogel

$1978{ }^{13} \mathrm{C}$ Content of Human Collagen as a Measure of Prehistoric Diet in Woodland North America. Nature 276:815-816.

Yarnell, Richard A

1978 Domestication of Sunflower and Sumpweed in Eastern North America. In The Nature and Status of Ethnobotany, edited by Richard I. Ford, pp. 289-299. University of Michigan Anthropological Papers No. 67. Museum of Anthropology, Ann Arbor, Michigan.

Submitted July 22, 2020; Revised September 24, 2020;

Reviews completed October 19, 2020; Accepted October 19, 2020 